\title{
ЗАРУБЕЖНЫЙ ОПЫТ СЕМЕЙНОЙ МЕДИАЦИИ *
}

\author{
(C) 2019 Курмаева Наталья Анатольевна \\ доцент, кандидат юридических наук, доцент кафедры правовых дисциплин \\ Национальный исследовательский Мордовский государственный университет им. Н.П. Огарёва, \\ Россия, Саранск \\ E-mail: kurmaeva_n@mail.ru

\section{(c) 2019 Галимова Линара Рафисовна} \\ магистрант кафедры правовых дисциплин \\ Национальный исследовательский Мордовский государственный университет им. Н.П. Огарёва, \\ Россия, Саранск
}

Авторами проанализирован зарубежный опыт проведения медиации по семейным спорам и высказаны предложения относительно повсеместного внедрения медиативных технологий при урегулировании семейно-правовых конфликтов в России. При этом активная роль в проведении процедуры медиации должна принадлежать психологу, специализирующемуся в области семейной и возрастной психологии. Высказано предложение о необходимости создания Служб судебных психологов в субъектах Российской Федерации, одним из направлений деятельности которых должно являться проведение медиации по семейным спорам.

Ключевые слова: альтернативный способ разрешения споров, медиация, медиатор, медиативное соглашение, семья, семейная медиация, семейный спор, психолог.

Согласно Хартии о международной семейной медиации во всем мире в качестве эффективного средства разрешения и урегулирования конфликтов признается медиация [17, С. 182]. Причем, одним из наиболее востребованных видов медиации в зарубежных странах является семейная медиация, пользующаяся популярностью и признанием уже несколько десятилетий [9, С. 127].

Как правило, необходимость в применении семейной медиации возникает при расторжении брака между супругами в случае возникновения споров о месте проживания несовершеннолетних детей и определения условий общения с ними, раздела совместного нажитого в период брака имущества, установления размера и порядка уплаты алиментов и урегулирования других семейно-правовых конфликтов [2].

Процедура медиации проводится при взаимном волеизъявлении сторон на основе принципов добровольности, равноправия сторон, конфиденциальности, независимости, беспристрастности, принятия во внимание прав и интересов детей. В результате стороны конфликта самостоятельно приходят к взаимоприемлемому решению, выраженному в медиативном соглашении.
В отличие от судебного разрешения спора важнейшим преимуществом семейной медиации выступает возможность наиболее приемлемого разрешения конфликта на взаимовыгодных условиях для обеих сторон. Строгое соблюдение конфиденциальности при проведении процедуры медиации позволяет сохранять в тайне информацию, сообщенную в процессе рассмотрения спора, даже если в будущем стороны примут решение обратиться в суд для дополнительного решения конфликта.

Именно семейная медиация позволяет достичь взаимопонимания и взаимоуважения между членами семьи, выступающих в качестве основных моральных ценностей в таких странах, как США, Канада, Великобритания, Австралия, Новая Зеландия, принадлежащих к англосаксонской системе права [1, С. 135]. Семейная медиация получила достаточно широкое распространение и в таких странах, как Германия, Австрия, Франция, Дания, Бельгия, Финляндия, Италия, Ирландия.

В качестве примера рассмотрим особенности применения процедуры семейной медиации в отдельных зарубежных странах.

В Соединенных Штатах Америки медиация является эффективным инструментом для раз-

* Исследование выполнено при финансовой поддержке РФФИ в рамках научного проекта № 19-011-00570 
решения семейно-правовых споров. Суд вправе назначить проведение примирительной процедуры по делам о расторжении брака, если сочтет возможным сохранение семьи. Вынесение такого решения не зависит от желания самих супругов. Примирительная процедура осуществляется постоянно действующими службами по примирению или органами, создаваемыми для урегулирования конкретного спора в соответствии со ст. 404 Единообразного закона о разводе США [4].

Кроме того, проведение семейной медиации предусмотрено по спорам, связанным с распределением прав и обязанностей по воспитанию ребенка [7, С. 179], а также с разделом совместно нажитого имущества между супругами.

Значительное внимание вопросам семейной медиации уделяется в Европейском Союзе. 21 января 1998 года была принята Рекомендация Комитета Министров Совета Европы № $\mathrm{R}$ (98) 1 о семейной медиации. В рекомендации отмечается, что растущее число семейных споров оказывает пагубное воздействие на семью, как в социальном, так и экономическом плане. В связи с этим необходимо обеспечивать защиту наилучших интересов ребенка. Отмечаются такие особенности семейных споров, как возможность продолжения отношений, особая эмоциональность, негативное влияние на всех членов семьи, и особенно на детей. В связи с этим применение семейной медиации позволит улучшить отношения между членами семьи, сгладить конфликт противоборствующих сторон, обеспечить преемственность личных взаимоотношений между родителями и детьми, снизить экономические издержки в связи с разрешением возникших разногласий и сократить продолжительность времени, необходимого для урегулирования конфликта [19].

Европейский кодекс поведения медиаторов, принятый в Брюсселе 2 июля 2004 года устанавливает ряд принципов, которых должны придерживаться медиаторы, в том числе особое внимание при разрешении семейных споров следует уделять интересам ребенка [3].

Первой страной, где активно применяется медиация для урегулирования семейноправовых споров стала Великобритания [5, C. 130]. Система семейной медиации в Англии и Уэльсе достаточно хорошо внедрена и прекрасно поддерживается. Совет по семейной медиации объединяет шесть ведущих организаций, в число которых входит Ассоциация семейных медиаторов. В Англии осуществляется государственное финансирование данной сферы. До обращения в суд по семейным вопросам необходимо посетить информационную встречу для знакомства с процедурой медиации. Медиаторы должны пройти признаваемое государством обучение и сдать государственный экзамен, прежде чем смогут проводить информационные встречи и медиацию в рамках оказания правовой помощи. Они должны обладать опытом профессионального консультирования и проходить регулярную процедуру экспертной оценки своей работы. С января 2013 года обязательное требование посещать информационные сессии для знакомства с процедурой медиации распространилось практически на всех лиц, обращающихся в суд по семейно-правовым спорам [16].

Наиболее широкое распространение семейная медиация получила в Германии. Медиация необходима при возникновении споров, касающихся воспитания детей, установления опеки, раздела недвижимого имущества, распределения долгов, конфликтах, связанных с выполнением условий брачного договора [10, С. 446], для разрешения наследственных споров. В результате проведения медиации супруги приходят к обоюдному решению [20, С. 67].

В настоящее время в Германии семейную медиацию вправе проводить частнопрактикующие медиаторы, а также государственные служащие управлений по делам молодежи по спорам, связанным с воспитанием детей. Для проведения семейной медиации привлекаются специалисты, обладающие специальными знаниями в области психологии.

В Австрии порядок проведения процедуры медиации регламентируется Федеральным законом о медиации в гражданской сфере, Регламентом об образовании медиаторов в гражданской сфере, Законом о медиации Европейского союза [12]. Медиация используется при разрешении гражданских, трудовых, семейных и других конфликтов [8, С. 270].

В Австрии семейная медиация осуществляется двумя медиаторами, один из них - это специалист в области психологии (семейный психолог или психотерапевт), а другой - юрист (адвокат, специализирующийся по семейным делам или нотариус) [14, С. 456]. Такая практика является достаточно эффективной, поскольку при проведении медиации по данной категории 
споров необходимо соблюдать правовые нормы, а также учитывать социально-психологические и личностные качества ее участников [11, С. 522].

В Дании процедура медиации по семейным спорам проводится в обязательном порядке [18]. В Областную государственную администрацию могут бесплатно обратиться лица, у которых возникают сложности с установлением опеки или реализацией прав на общение с ребенком [16]. Если спор не удается разрешить путем проведения медиации, то дело передается на рассмотрение суда, где также сторонам предлагается примириться.

Медиация широко распространена и в странах Северной Европы. Например, в Финляндии глава 5 Закона о браке содержит нормы о мирном урегулировании споров между супругами в случае развода. Члены семьи вправе обратиться к медиатору за содействием и поддержкой. Медиация является конфиденциальной и учитывает интересы всех участников спора, причем первостепенное значение имеют интересы несовершеннолетних детей. Медиацию проводят как специализированные государственные учреждения, так и частнопрактикующие медиаторы. Контроль за их деятельность осуществляют уполномоченные государственные органы Министерства социальных дел и здравоохранения Финляндии [7, С. 181].

В Италии обращение к медиатору по семейным спорам не является обязательным. Однако данная процедура применяется по инициативе судьи при рассмотрении судом дела о расторжении брака, а также в случаях выявления фактов семейного насилия [16]. К основным законодательным актам, регламентирующим медиацию в Италии, относятся Законодательные декреты о медиации, Министерские декреты и Закон от 9 августа 2013 года [13].

В Ирландии Служба семейной медиации предоставляет медиативные услуги, финансируемые за счет государства. Однако желающих обратиться в данную службу довольно много, в связи с чем многие супружеские пары вынуждены обращаться к частным медиаторам, работающим на коммерческой основе [16].

Исходя из вышеизложенного, можно сделать вывод о том, что семейная медиация - это обособленный и наделенный уникальными характеристиками альтернативный способ разрешения споров. Активное применение процедуры медиации при разрешении семейных споров по сравнению с судебным порядком имеет существенные преимущества, позволяя сохранить дружественные отношения между бывшими супругами и защитить интересы их несовершеннолетних детей. «Именно медиатор находит решение, удовлетворяющее интересы обеих сторон, в отличие от решения суда, которое выполняет репрессивную функцию государства и удовлетворяет интересы одной стороны» [23, С. 99].

Опыт зарубежных стран имеет решающее значение для развития семейной медиации в России [6, С. 31]. При этом следует обратить внимание на то, что как, например, в Австрии, наиболее эффективным будет привлечение психолога, специализирующегося в области семейной и возрастной психологии. В субъектах Российской Федерации необходимо создать Службы судебных психологов, одним из направлений деятельности которых должно являться проведение медиации по семейным спорам.

\section{Библиографический список}

1. Бодрова Е.А. Современная форма семейной медиации в России и за рубежом // Вестник РГГУ. Серия: Экономика. Управление. Право. - 2015. - № 1 (144). - С. 134-137.

2. Буянова E.B. Особенности процедуры медиации в семейных спорах: анализ зарубежного опыта // Труды Оренбургского института (филиала) Московской государственной юридической академии.- 2016.№ 30.- С. 71-79.

3. Европейский кодекс поведения медиаторов от 02.07.2004 г.- URL: http://base.garant.ru/70515162/ (дата обращения 14.08.2019)

4. Елисеева Т.С. Зарубежный опыт правового регулирования процедуры альтернативного разрешения споров // Юридический мир. - 2015. - № 6.- URL: http://xn--7sbbaj7auwnffhk.xn - p1ai/article/15071 (дата обращения 14.08.2019)

5. Ивановская Н. В. Медиация в Англии и Уэльсе // Вестник РУдН. Серия: Юридические науки. - 2013. - № 1.C. $130-135$. 
6. Исаенкова О.В. Использование опыта Республики Беларусь и других государств для развития семейной медиации в России // Медиация в семейном конфликте: сборник материалов II Всероссийской научнопрактической конференции.-2018.- С. 30-35.

7. Калашникова С.И. Медиация в сфере гражданской юрисдикции: дис. ... канд. юрид. наук.-Екатеринбург, 2010.- 257 с.

8. Коломытцева В.В. Этапы становления медиации в зарубежных странах // Вестник ТГУ.- 2013.- № 2.C. 268-272.

9. Кутюков Д.В. Медиация как альтернативный способ разрешения конфликтных ситуаций // Государство и право: теория и практика: материалы междунар. науч. конф.- Челябинск, 2011.- С. 127-129.

10. Лосякова К.А., Худойкина Т.В. Применение семейной медиации в России и в европейских странах // Вестник современных исследований. - 2018. - № 6.2 (21).- С. 446-447.

11. Оганесян Д.А. Медиация в европейском семейном праве // Вестник современных исследований. - 2018.№ 5.4 (20). - С. 520-522.

12. Официальный сайт ФГБУ «Федеральный институт медиации».- URL: http://fedim.ru/mediatsiya-v-mire/ evropa/avstriya/ (дата обращения 14.08.2019)

13. Официальный сайт ФГБУ «Федеральный институт медиации».- URL: http://fedim.ru/mediatsiya-v-mire/ evropa/italiya/ (дата обращения 14.08.2019)

14. Пантеева И.А. Семейная медиация как альтернативная процедура разрешения споров // Вестник ННГУ.2014. - № 1.- С. 452-457.

15. Садовникова М.Н., Раднаева Э.Л. Дружественное к ребенку правосудие и восстановительно-медиативные технологии: аналитический обзор научно-практических форумов Восточной Сибири // Сибирский юридический вестник. - 2016. - № 1.- С. 99.

16. Ташевский С. Большой диалог о семейной медиации // Медиация и право. Посредничество и примирение. 2013. № 1 (27). - URL: http://edition.vogazeta.ru/ivo/info/14517.html (дата обращения 14.08.2019)

17. Хартия о международной семейной медиации // Вестник федерального института медиации.- 2017.№ $1 .-$ C. 181-188.

18. Casals M.M. Divorce Mediation in Europe: An Introductory Outline // Electronic Journal of Comparative Law.2005. - Vol. 9.2. - P. 1-24. - URL: https://www.ejcl.org/92/art92-2.html (дата обращения 14.08.2019)

19. Recommendation No. R (98) 1 of the Committee of Ministers to member states on family mediation.- URL: https://rm.coe.int/CoERMPublicCommonSearchServices/DisplayDCTMContent?documentId=09000016804ecb 6e\#\%20search=recommendation\%20family\%20mediation (дата обращения 14.08.2019)

20. Thomas Trenczek, Serge Loode. Mediation «made in Germany» - a quality product // ADRJ. - 2012.- № 23.- P. 61-70.- URL: https://www.researchgate.net/publication/228096531_Mediation_made_in_Germany_-_a_quality_ product (дата обращения 14.08.2019) 